\title{
STUDENTS' PERCEPTION TOWARD ROLE PLAY ACTIVITY IN THE ESP CLASS ROOM
}

\author{
Endang Setiyo Astuti \\ Program Studi Pendidikan Bahasa Inggris \\ IKIP Budi Utomo Malang \\ mynameisendang@gmail.com
}

\begin{abstract}
Abstrak: Pembelajaran bahasa Inggris yang dikhususkan dalam konteksbidang tertentu dikenal dengan ESP (BahasaInggrisuntuktujuankhusus). Tujuannya adalah untuk mengembangkan potensi linguistic mahasiswa yang membutuhkan pengetahuan bahasa di bidangnya.Sejalan dengan tujuannya, pembelajaran ESP dilakukan dengan mengajarkan keterampilan berbahasa, salah satunya adalah keterampilan berbicara. Penelitian inidilakukan di sebuah Akademi Kebidanan di Malang, yang melaksanakan program ESP bagi mahasiswanya. Dalam proses pembelajarannya, salah satu instruktur menerapkans trategi roleplay karena melihat bahwa strategi ini dapat memotivas imahasiswa untuk aktifberbicara bahasaInggris. Maka, tujuan penelitian ini adalah untuk mendeskripsikan bagaimana kegiatan roleplay dilakukan di kelas ESP dan apa persepsi mahasiswa terhadap kegiatan roleplay. Penelitian ini menggunakan metodedeskriptifkualitatif yang menggunakan angket, interview, dan observasi sebagai instrument untuk mengumpulkan data. .Hasilnya menunjukkan bahwa mahasiswa memiliki persepsi yang positif terhadap kegiatan dalam roleplay karena mereka berkesempatan untuk berlatih berbicara bahasa Inggrisdengan mengalam isituasi yang seolah-olah nyata di dunia kerja sehingga meningkatkan percaya diri mereka.Kegiatan dalam roleplay juga dapat meningkatkan interaksi di antara mahasiswa.
\end{abstract}

Kata kunci :persepsi, role play, ESP

The demand of professionals competent in English is unavoidable nowadays. Hence, people in all disciplines are making such efforts to prepare themselves in the job fields. It is also done by colleges of health services, such as pharmacy, nursing, and mid wifery, in which they oblige the students to take English class. It is specified to the students' need in their area of work or study. The English program is known as English for Specific Purposes (ESP). Hutchinson (1986) defined ESPas a language teaching given to the students who have professional study and job-related reason so that English is used in common context or in the context of the students' subject area. The aim of the ESP program is to develop the linguistic potentialities of the students who need the language to update knowledge in their specialties.Regarding with the purposes of the program, the teaching learning of ESP is also done by teaching the students the language skills. One language skill taught in ESP is speaking skillsince it is essential skill that should be mastered by students.

However, the students face problems in speaking such as difficulty to arrange the sentences, fear of making mistakes, and lack of motivation as Nunan (1992) stated that there are some challenges in teaching speaking skill in English as a Foreign Language (EFL) classroom namely lack of motivation, and they are prone to use their first language. Furthermore, Deller (2007) explains that it is not easy to get students to speak about unfamiliar topics because they need more time to prepare and focus on the content in English.This was also experienced by the ESP lecturer of dr. Soepraoenmidwifery academy in which the students were reluctant to speak English because of the shyness and the fear of making mistakes. The assigned topics which were not related to their area of study often made them in difficulty to speak English.

Related to those problems, an activity that was applied by the lecturer in the ESP classroom was role play, thatis an activity leading the students to play such a drama. The student plays a role to be another person in a certain situation. Such a situation leads the researcher to do this study in which the objective is to know how the role play activity was done in the ESP classroom and what the students' perceptions toward the role play activity are. Ladousse (2009) stated that 
role play is an enjoyable activity and does not threaten the students. So, it is important for the students to practice the speaking skill by pretending to behave in the real situation. Nestel and Tierney (2007) also added that role play is used to acquire knowledge, attitudes, and skills in learners of all ages. It is suitable for the adult students as well to do such activity in the ESP classroom. Besides it can also be done in any discipline of knowledge, as DeNeve and Heppner, (1997) supported that over the years role play has become a teaching technique in many diverse settings and disciplines, such as communications, crosscultural training, industrial psychology, business, management, marketing, economics, law, law enforcement, medicine, political science and sociology. According to Byrne (1986) role play can be grouped into two forms, scripted and unscripted role play. Scripted role play involves interpreting either the textbook dialogue or speaking text in the form of speech. The main function of the text after all is to convey the meaning of language items in a memorably way. In contrast to scripted role play, the situations of unscripted role play do not depend on textbooks. It is known as a free role play or improvisation. The students themselves have to decide what language to use and how the conversation should develop.

Meanwhile, to achieve the purpose of learning English through the role play activity, it is important to know the students' perception toward the activity. Szilagyi and Wallace (1980) defined perception as a process by which individuals attend to incoming stimuli, organize, and then interpret such stimuli into a message that in turn indicates an appropriate action or behavior. Huffman et al (1997) added that perception is the process of selecting, organizing, and interpreting sensory data into usable mental representations of the world. This means that someone can receive something as good or bad perception depends on what they feel in facing the object. So, positive perception on learning activities affects students' behavior to have higher motivation in the learning process.

\section{METHOD}

This research used the descriptive qualitative design. The subject of this research was the students of midwifery academy.The instruments used to collect the data were interview, questionnaire, and observation. The interview was done to get the information from the lecturer about the reason why role play was applied in the ESP class. Questionnaire was distributed to the students of midwifery academy in order to know about their perception toward the role play activity. It used the Likertscale in which the students responded by choosing either Strongly Agree (SA), Agree (A), Disagree (D), or Strongly Disagree (SD) to the ten statements. The observation was done by the researcher to the activity of role play in classroom regarding with the engagement of students in the process of role play activity in the classroom. The participants of this research were 42 female students of midwifery academy. They consisted of 23 students from class A and 19 students from class B.

\section{FINDINGS AND DISCUSSION \\ Questionnaire}

There were ten statements concerning with the perception of the students towards the role play activity in English class needed to respond by the students. The statements were classified into two topics consisted of three statements about the importance of learning English for their future job as midwives and seven statements about the advantages of learning English through role play activity in the classroom (see Appendix). The result is showed in the following table:

\begin{tabular}{|c|l|c|c|c|c|}
\hline No & \multicolumn{1}{|c|}{ Statements } & $\begin{array}{c}\text { Strongly } \\
\text { Agree }\end{array}$ & Agree & Disagree & $\begin{array}{c}\text { Strongly } \\
\text { Disagree }\end{array}$ \\
\hline 1 & $\begin{array}{l}\text { The importance of learning English } \\
\text { for their future job. }\end{array}$ & $15 \%$ & $82 \%$ & $3 \%$ & $0 \%$ \\
\hline 2 & $\begin{array}{l}\text { The advantages learning English } \\
\text { through role play activity. }\end{array}$ & $8 \%$ & $88 \%$ & $2 \%$ & $0 \%$ \\
\hline
\end{tabular}


In general, the average result above showed that more than $90 \%$ students had positive perception toward the role play activity in the ESP classroom. Regarding with the importance of English in their area of study, 15\% students strongly agreed and $82 \%$ students agreed to learn English in the college because it was useful to support their future job while only 3\% students disagreed that English was not important for their future job. The responses concerning with the advantages of role play activity in the ESP classroom showed that $8 \%$ students strongly agreed, $88 \%$ students agreed, and $2 \%$ students disagree.

\section{Interview}

From the interview with the lecturer, it was known that role play was the suitable activity for the students of ESP class because they could practice playing roles as what they would get in the future after graduating from this academy. In terms of the topic assigned to the students, the lecturer said that it should be the familiar one and required their need. Since they were the students of midwifery academy, the roles they played would be as the midwives, the patients or pregnant women with the problems regarding the pregnancy. It was quite relevant with the purpose of this academy that is to prepare them to be skillful midwives. Moreover, the students could practice their speaking skill in this activity, especially the vocabulary and pronunciation. Scripted role play was chosen by the lecturer to do the activity in which the students could firstly write the dialog and discuss it with their partners in group before presenting in front of class.

\section{Observation}

From the observation done by the researcher in two classes $\mathrm{A}$ and $\mathrm{B}$, it was found that the students were ready in experiencing the learning process. Only some students from two groups were not ready in presenting the roles. All the students were cooperative in doing the activity. It was shown by the preparation they had before the presentation. The students cooperated to each other to set the classroom into a clinic-like-room. Besides they also prepared some properties such as a baby doll, stethoscope, blood pressure gauge, thermometer, etc. to support their performance. All the students were responsible with the assigned roles and tried to speak actively although some of them still mixed English with bahasa Indonesia. Some others sometimes looked up the notes when they forgot the dialog. In general, the conversations were understandable. The students looked confident in performing the play. The mistakes made by the students in terms of pronunciation and grammar were not given feedback immediately, but after the performance by the teacher. Most of the plays ran quite well.

\section{CONCLUSION}

Role play activity has positive impact in improving students' speaking skills as it gives the students a chance to explore different situations of real life and enables them to speak English confidently in that situation. Although during role play in a large class room, the situation gets confusing and the performerssometimes forget their dialogues, which create embarrassment, the students usually try to finish the assignment well.Teachers may give immediate verbal feedback or written feedback in case of technical difficulties while recording acts.

\section{REFERENCES}

Byrne, D. 1986. Teaching Oral English: Longman Handbooks for English Teachers. Singapore: Longman Group.

Deller,S. \& Price, C. 2007. Teaching Other Subjects through English. Oxford University Press

DeNeve, K. M. \& Heppner, M. J. 1997. Role Play Simulations: The Assessment of An Active Learning Technique and Comparisons with Traditional Lectures. Innovative HigherEducation, 21(3), 231-246.

Huffman, et al.,1997.Psychology in Action. $4^{\text {th }}$ Edition. Canada: John Wiley \& Sons, Inc.

Hutchinson, T \& Waters, A. 1987.English for Specific Purpose, A Learning Centered Approach. Cambridge: Cambridge University Press.

Ladousse, G. 2009. Role Play.New York: Oxford University press. Littlewood, W. 1981.Communicative Language Teaching. Oxford: Oxford University

Nestel, D. \& Tierney, T.2007.Role-play for Medical Students Learning about Communication: Guidelines for Maximizing Benefits. BioMed Central Medical Education, 1-9. 
32|| Endang Setiyo Astuti, Students' Perception Toward Role .....

Nunan, D. 1992. Research Methods in Language Learning. New York: Cambridge University Press.
Szilagy, Andrew D. et al, 1980. Organizational Behavior and Performances. California: Good Year Publishing Company, Inc. 